\title{
CALVYN SE INVLOED OP DIE GRIEKSE KERK
}

\author{
Die merkwaardige geskiedenis van patriarg Cyrillus \\ Lukaris van Konstantinopel
}

\section{Die toestand van die Griekse Kerk aan die begin van die 17e eeu}

Terwyl die Reformasie van die kerk in Wes-Europa gedurende die $16 \mathrm{e}$ eeu die grootste deurbraak beleef het en die vestiging van die Gereformeerde Kerk 'n voldonge feit geword het en Rome fanatiek sy verlore terrein met die Kontrareformasie probeer herwin het, worstel die Christelike kerk in die lande van Oos-Europa en die Midde-Ooste in 'n eensame stryd voort. Aan die begin van die $17 \mathrm{e}$ eeu is hierdie kerk, wat ons nader spesifiseer as die Grieks-Ortodokse Kerk, nog steeds onder die juk van die Turke met die godsdiens van die Islam. In Konstantinopel waar die patriarg sy setel gehad het, was die toestand van die kerk ellendig en droewig. Sy bestaansmoontlikheid is bedreig en sy ontwikkeling is gestrem. ${ }^{1}$ As ons daaraan dink dat in die 500 jaar van oorheersing deur die Turke daar uit 'n totaal van 159 patriarge slegs 21 aan 'n natuurlike dood gesterf het, dan vertel dit die somber verhaal van moord, lyding en geloofsvervolging. ${ }^{2}$

Behalwe die uiterlike somber beeld van die kerk in die Ooste, het teologiese verval ook 'n innerlike verlamming gebring. Die Ooste is langduriger en indringender beheers deur die Griekse denke. Spoedig het die verskil met die kerk in die Weste ingetree by die teologiese stryd oor die drie-eenheid en Christus se persoon. ${ }^{3}$ Die dogma dat die Heilige Gees nie alleen uitgaan van die Vader nie, maar ook van die Seun (,filioque") ${ }^{4}$ is in 'n neutedop die verskil tussen die Oosterse en Westerse teologie (W. J. Aalders). Vandat die Weste by die Sinode van Toledo in 589 die "filioque" in die Nicaeno-Constantinopolitanum tussen die woorde "ex Patre” en „procedentum" ingevoeg het, ${ }^{5}$ was dit net 'n kwessie van tyd voordat die skisma in wese sou voltrek word toe pous Leo IX deur sy kardinaal Humbert die banbul op die altaar van die Hagia Sofia in Konstantinopel neergelê het en die Oosterse kerk toe finaal van die Weste geïsoleer geraak het. ${ }^{\theta}$ Dit lê voor die hand dat kontak met die Reformasie van die kerk in die Weste in die 16e eeu dus uiters moeilik was.

Boonop moet nog geboekstaaf word dat die rol wat Rome met die Kontra-reformasie aangevuur deur die Jesuite-fanatisme as 'n reaksiebeweging teen die Hervorming, die moontlikheid van beinvloeding deur manne soos Luther en Calvyn, nog meer bemoeilik het. ${ }^{7}$

Teen die agtergrond van sulke moeilike omstandighede, moet ons dan die betekenis van die patriarg Cyrillus Lukaris vir die Oosterse kerk in die $17 \mathrm{e}$ eeu sien. Dan sal ons ook iets meer van Calvyn se betekenis begryp. 


\section{Iets oor die persoon van Cyrillus Lukaris}

Dit is besonder opvallend hoe dat die meeste Ensiklopedieë dit baie prominent stel dat Cyrillus Lukaris, die patriarg van die Oosters-ortodokse Kerk van Konstantinopel, 'n calvinis was. Alleen literatuur vanuit die hoek van die Oosterse Kerk self hou nie baie daarvan om hierdie feit te onderstreep nie en kom by 'n positiewe waardering van sy teologie nie verder nie as 'n erkenning dat dit 'n „uitsondering" in die Griekse Kerk was. Nicolas Zernov sê: „Cyril's active interest in Western theology was an exception, rather than a typical example of the Orthodox attitude..." 8

Cyrillus Lukaris is op 13 Nov. 1572 (d.w.s. dieselfde jaar as „Barthelomeusnag”!) gebore op die eiland Kreta en op 27 Junie 1638 is hy vermoor. Sy oorspronklike naam was Konstantinos. Vanaf sy $12 \mathrm{e}$ tot sy $23 \mathrm{e}$ jaar studeer hy in Venisië en Padua en daarna was hy vir ongeveer sewe jaar werksaam aan die Universiteite van Litaue en Pole. In 1602 word hy patriarg in Alexandrië en in 1621 word hy benoem tot die hoogste amp van die Griekse Kerk, nl. patriarg van Konstantinopel. ${ }^{\circ}$

\section{Kontak met Nederlanders}

Dit is ' $n$ bekende feit dat die Republiek van die Nederlande juis kort na die Sinode van Dordrecht (1618-19) toe die Drie Formuliere in die Belydenis van die Gereformeerde Kerke sy beslag gekry het, 'n bloeitydperk op die gebied van die wêreldhandel beleef het waardeur die Nederlandse invloed ver deurgedring het. Veral in die konkurrensie met Frankryk (met die magsgreep van die Rooms-Katolisisme), was dit juis calvinistiese Nederlanders wat 'n blywende stempel op baie plekke in die wêreld kon afdruk. Is Suid. Afrika dan nie ook 'n tipiese voorbeeld daarvan nie?

Waar die Nederlandse invloed in die Midde-Ooste egter nooit soos in Suid-Afrika tot 'n volksplanting kon kom nie en menslik gesproke miskien die minste kanse gehad het, het dit tog deurgedring tot die patriarg van die Grieks-Ortodokse Kerk. ${ }^{10}$

Onder die Nederlanders wat direkte kontak met Cyrillus Lukaris gehad het, was die Nederlandse gesant in Konstantinopel, nl. Cornelis Haga en ' $n$ bekwame handelaar met die naam van Dawid le Leu de Wilhelm. ${ }^{11}$ Waar die patriarg alreeds vantevore groot belangstelling vir die Protestantisme in die Weste getoon het, het hierdie twee Nederlanders positiewe pogings aangewend om hom te beinvloed om die Calvinisme heeltemal aan te neem. Dat dit die Protestantisme met die Calvinistiese aksent was, is veelseggend, aangesien 'n poging van Lutherse kant teen die einde van die $16 \mathrm{e}$ eeu vantevore misluk het, nog voordat Lukaris patriarg geword het.12

Genoemde twee Nederlanders het egter veel reg gekry. Die eerste poging wat hulle aangepak het, was om Lukaris van literatuur te voorsien en daarvoor is selfs die hulp van die State Generaal ingeroep. ${ }^{13}$ Verder het hulle daarin geslaag om 'n korrespondensie tussen die patriarg en Johannes Utenbogaart te bewerkstellig. ${ }^{14}$ Weliswaar was laasgenoemde 'n Remonstrant en van die literatuur wat Lukaris 
bekom het, was daar nog meer met 'n remonstrantse inslag, maar tog was dit juis die calvinisties-gereformeerde beginsels wat eindelik vir hom 'n bekoring was. ${ }^{15}$ Hierdie feit word bevestig in ' $n$ brief van die Engelse gesant aan sy aartsbiskop Abbot: „As for the Patriarch himself, I do not doubt but that in opinion of religion he is, as we term him, a pure Calvinist, and so the Jesuits in these parts do brand him". ${ }^{16}$ Hierdie Engelse gesant wat in daardie selfde tyd ook 'n groot rol in die lewe van Cyrillus Lukaris gespeel het, was Sir Thomas Roe en só groot was hulle vriendskap dat die patriarg aan hom die wêreldberoemde Codex Alexandrinus (teks van die N.T.) geskenk het waardeur dit vandag nog in die Britse Museum is. ${ }^{17}$

\section{Kontak met Genève}

Intussen het Cornelis Haga, die Nederlandse gesant, hom beywer om 'n gereformeerde predikant te kry wat in Konstantinopel die lede van die gesantskap geestelik kon bedien. Dit was egter nie al motief nie, want hierin was dit ook 'n poging om 'n deurbraak vir die Calvinisme tot die Griekse Kerk te probeer vind. ${ }^{18}$ „Daar gaan op die oomblik groot deure oop vir die Evangelie", verklaar die Nederlandse gesant en hy versoek bowendien dat die man wat moet gestuur word bekwaam onderlê moes wees in Grieks en Hebreeus en dat hy die Italiaanse taal goed moes ken. ${ }^{19} \mathrm{Na}$ enige moeite het die kerk in Genève daarin geslaag om die dienste van ds. Antonie Lèger te verkry, 'n predikant van St. Martin in die valleie van Piedmont.

Met ds. Lèger het daar nou vir 'n geruime tyd 'n verbinding tussen die kerke van Genève en Konstantinopel gekom waardeur die Calvinistiese belydenis ' $n$ wonderlike deurbraak gevind het. Daar was selfs sprake van 'n vereniging (unie) tussen die kerke in die twee verskillende stede en oor die volgende voorwaardes is ooreengekom: 1. dat in alle geskille God se Woord die beslissing sou hê, 2. dat vir die uitlegging van moeilike Skrifgedeeltes, die kerkvaders se getuienis sou ingeroep word, en 3. dat elke kerk sy eie liturgie sou behou, tensy dit kan bewys word dat dit strydig is met God se Woord.20 Hierby het ook nog gekom dat die Belydenisskrifte wedersyds uitgeruil is vir studie en bywoning van mekaar se kerkdienste is georganiseer. ${ }^{21}$

\section{Invloed van die Nederlandse Geloofsbelydenis (Confessio Belgica)}

In 1627 is 'n Latynse en Griekse vertaling van die Ned. Geloofsbelydenis wat deur Revius, die predikant van Deventer bewerk is aan Cyrillus Lukaris gestuur, sowel as 'n Griekse vertaling van die Heidelbergse Kategismus deur Hommius. ${ }^{22}$

Die invloed van hierdie twee uitstaande gereformeerde belydenisskrifte, het aan die invloed van Calvyn en die gereformeerde kerke 'n direkte deurgang gegee. Dit het nie alleen Cyrillus Lukaris se teologie verdiep nie, maar die patriarg het die behoefte aan onderwysing van sy eie mense deur die regte skole en 'n suiwer 
belydenisskrif ernstig begin aanvoel. Vir 'n kerk waar die preekstoel nie eens meer as 'n stuk huisraad gedien het nie en waar die prediking heeltemal verdwyn het, ${ }^{23}$ was dit 'n geweldige ding!

Onder toeneming van vyandskap, veral aangevuur en subtiel in die kerk ingedra deur die Jesuïte, het Lukaris egter met beslistheid begin om in Konstantinopel 'n skool op te rig en vir hierdie doel het hy 'n Calvinistiese onderwyser aan die hoof geplaas met die naam van Corydalleus. ${ }^{24}$

In dieselfde tyd moes die Institusie van Calvyn ook van groot invloed gewees het, want nadat Lukaris op 'n keer aangekla is as ketter, het die Franse gesant (geïnspireer deur die Jesuîte) sarkasties opgemerk dat die patriarg as hy verban word na die eiland Rhodus, genoeg tyd sal hê om die Institusie te lees. ${ }^{25}$

\section{Cyrillus Lukaris se Belydenisskrif („,Confessio Fidei”) ${ }^{26}$}

In Maart 1629, kort nadat ds. Antonie Lèger in Konstantinopel aangekom het, is Lukaris se Kategismus, oftewel sy "Confessio Fidei" in Genẽve (let wel!) gedruk. Die eerste uitgawe was opgedra aan Cornelis Haga, die Nederlandse gesant. In 1631 is dit opgevolg met uitgawes in Grieks en Latyn en die derde druk was in Frans. ${ }^{27}$ Binne ' $n$ kort tyd daarna in die Confessio in baie meer Europese tale vertaal en selfs 'n verwerkte Engelse vertaling het verskyn onder die titel ,A Vindication of the Reformed Religion"..28

Sonder om in hierdie beperkte ruimte oor te gaan tot 'n breedvoerige bespreking van die Confessio se inhoud, is dit nodig om te konstateer dat ons hier 'n Belydenisskrif midde in die OostersOrtodokse Kerk het wat deur-en-deur 'n sterk Calvinistiese stempel dra waarin die gereformeerde simbole onmiskenbare spore vertoon. Let op die radikale uitstaande punte: die filoque word aanvaar; die uitverkiesing word gehandhaaf; die regverdiging deur die geloof en nie uit verdienste nie, word geleer; die twee sakramente word geleer en die beeldediens word bestry.

Betekenisvol is veral die belydenis oor die kerk en die verwerping van die valse ,ex opere operato" in die sakramente. Ook die leer oor die Vagevuur deur Rome, word verwerp.

Geen wonder nie, dat hierdie Belydenis bittere vyandskap in die Roomse Kerk en in die verstarde Oosterse Kerk ontlok het nie. Lukaris se eie kerk het in sinodes in 1638, 1642 en 1672 sy Confessio radikaal verwerp. ${ }^{29}$ Die vraag kom baie ernstig op: Kan 'n kerk wat die ,filioque" verwerp nog reformeer? As die Heilige Gees dan nie meer van Jesus Christus uitgaan nie, dan word die prediking van die Evangelie by die wortel afgesny en die kerk self berei die teelaarde vir die dwaling van die leuen. Lê die teologiese wortel van die Kommunisme nie reeds hier nie?

Lodewyk XIII van Frankryk het Lukaris se Belydenis gekwalifiseer as ,estant huguenot et entaché d'hérésie"..30 Die Gereformeerde Kerk in Suid-Holland het dit egter in 'n Partikuliere sinode in 1634 aangeprys as ,,suyvere religie", ${ }^{31}$ ook dat dit „omhelsde de leere van den overtreflijken doctor Johan Calvijn".

Wat was die verdere invloed van hierdie gereformeerde bely- 
denis in die Griekse Kerk? Die koringkorrel moes egter eers sterf! En sou dit na eeue miskien nog ontkiem? Dit sal die Kerkgeskiedenis seker nog aanwys.

\section{Cyrillus Lukaris se marteldood}

Ons het reeds opgemerk dat vyandskap gaandeweg opgelaai het teen hierdie uitnemende patriarg. Ruimte is te beperk om in te gaan op al die pogings om hom uit die weg te ruim en vir 'n breedvoerige relaas kan die uitmuntende werk van die Griekse Calvinis Hadjiantoniou, nl. sy „Protestant Patriarch" geraadpleeg word. In die somer van 1638 het Cyrillus Lukaris wat homself as patriarg verneder het onder die enigste Hoof van die Kerk, nl. Christus, se lewe tot 'n dramatiese einde gekom. Die ou subtiele metode is gevolg: Lukaris is by die Turkse owerheid verdag gemaak dat hy 'n opstand bewerk. $\mathrm{Hy}$ is in ballingskap gestuur en onderweg is hy oorboord in die see gegooi.

V. E. d'Assonville.

1 A. A. van Schelven: Uit den strijd der geesten, Amsterdam, 1944, bl. 138.

2 Nicolas Zerov: Eastern Christendom, Londen, 1961, bl. 135.

3 H. Berkhof en O. J. de Jong: Geschiedenis der Kerk, Nijkerk, 1967, bl. 68.

4 Sien vir breedvoerige literatuur: A. D. R. Polman: Onze Nederlandsche Geloofsbelijdenis, deel 2, Franeker (ongedateerd), bl. 40 e.v.

5 J. N. Barkhuizen van den Brink: Handboek der Kerkgeschiedenis, deel 1, Den Haag, 1965, bl. 209.

6 Ibid, deel 2, bl. 63.

7 A. A. van Schelven: op. cit.

8 Zernov: op. cit., bl. 139.

9 Sien die biografie oor Cyrillus Lukaris deur George A. Hadjiantoniou: Protestant Patriarch, Londen, 1961.

10 Vgl. A. A. van Schelven: op. cit., bl. 140.

11 Ibid.

12 W. Engels: Tübingen und Byzanz, soos aangehaal deur A. A. van Schelven: op. cit., bl. 134.

13 Van Schelven: op. cit, bl. 142.

14 Op. cit., bl. 142.

15 L. Praamsma: artikel in Christelijke Encyclopedie, „Cyrillus Lukaris”, deel 2, bl. 343, Kampen, 1957.

16 Hadjiantoniou: op. cit., bl. 59.

17 Calendar of State Papers, soos aangedui deur Van Schelven: op. cit., bl. 145.

18 Van Schelven: op. cit., bl. 145.

19 Legrand: Bibliographie Hellenique du XVII Ciecle, vol. iv, bl. 353 e.v., soos aangehaal deur Hadjiantiou: op cit., bl. 91.

20 Van Schelven: op. cit., bl. 146.

21 Ibid.

22 Ibid.

23 Hadjiantoniou: op. cit., bl. 51.

24 Op. cit., bl. 71.

25 Van Schelven: op. cit., bl. 149. 
26 Sien bylaag. (Indien hierdie artikel in 'n tydskrif gepubliseer word, sal daar waarskynlik nie ruimte vir die bylaag wees nie.)

27 Hadjantoniou: op. cit., bl. 95.

28 Ibid.

29 L. Praamsma: op. cit.

30 Van Schelven: op. cit., bl. 148.

31 Ibid. 